\title{
Evaluation of the Cytotoxic Potential of Adhesives, with Two on the Market: Scotchbond Universal and Optibond Solo Plus, and an Adhesive in the Experimental Phase: $\mathrm{T1}^{\dagger}$
}

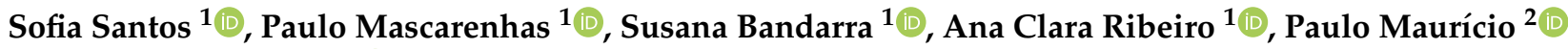 \\ and Isabel Barahona ${ }^{1, *(1)}$ \\ 1 Laboratório de Biologia Molecular, Centro de Investigação Interdisciplinar Egas Moniz (CiiEM), \\ Instituto Universitário Egas Moniz (IUEM), 2829-511 Caparica, Portugal; sosantos@gmail.com (S.S.); \\ pmascarenhas@egasmoniz.edu.pt (P.M.); sbandarra@egasmoniz.edu.pt (S.B.); \\ acribeiro@egasmoniz.edu.pt (A.C.R.) \\ 2 Clínica Dentária Egas Moniz, Instituto Universitário Egas Moniz (IUEM), 2829-511 Caparica, Portugal; \\ dmauricio@netcabo.pt \\ * Correspondence: ibarahona@egasmoniz.edu.pt \\ + Presented at the 5th International Congress of CiiEM-Reducing Inequalities in Health and Society, Online, \\ 16-18 June 2021.
}

Citation: Santos, S.; Mascarenhas, P.; Bandarra, S.; Ribeiro, A.C.; Maurício,

P.; Barahona, I. Evaluation of the Cytotoxic Potential of Adhesives, with Two on the Market: Scotchbond Universal and Optibond Solo Plus, and an Adhesive in the Experimental Phase: T1. Med. Sci. Forum 2021, 5, 7. https://doi.org/10.3390/msf2021005007

Academic Editors: Helena Barroso and Cidália Castro

Published: 11 July 2021

Publisher's Note: MDPI stays neutral with regard to jurisdictional claims in published maps and institutional affiliations.

Copyright: (c) 2021 by the authors. Licensee MDPI, Basel, Switzerland. This article is an open access article distributed under the terms and conditions of the Creative Commons Attribution (CC BY) license (https:// creativecommons.org/licenses/by/ $4.0 /)$.

\begin{abstract}
In vitro studies evaluating the cytotoxic potential of substances released from dental adhesives are lacking. The purpose of this study was to compare the cytotoxicity of the extracts of dental adhesives Scotchbond Universal and Optibond Solo Plus, and an adhesive in the experimental phase: T1. 3T3 mouse fibroblast cells and MG-63 osteoblast-like cells from human osteosarcoma were exposed for $24 \mathrm{~h}$ to serial extract dilutions. Cytotoxicity was determined using an MTT assay. For both cell lines, the cytotoxicity order obtained, of the unfiltered adhesive extracts, was T1 (less cytotoxic) < Optibond Solo Plus < Scotchbond Universal (most cytotoxic).
\end{abstract}

Keywords: dental adhesives; cytotoxicity; MTT Assay; cell viability

\section{Introduction}

Dental adhesives are widely used in dentistry. They serve as intermediate agents, which presupposes a direct and lasting contact with the dental structure. Studies show that after the application of adhesive agents to the already conditioned dentin, some residual monomers, from degradation or incomplete polymerization process, as well as other components of the adhesive systems, can penetrate and diffuse through the dentinal tubules and consequently reach the dental pulp, triggering inflammatory processes [1]. Resin monomers traditionally present in the composition of adhesive systems have a certain degree of cytotoxicity [2,3]. New adhesives are being produced permanently with better adhesive properties and easier application, but for long lasting restoration, they also have to be biocompatible. The purpose of this investigation was to evaluate the cytotoxic potential of three types of adhesives, the Scotchbond Universal (two-step self-etch universal generation adhesive), Optibond Solo Plus (two-step Etch-Rinse or one-step self-etch 5th generation adhesive), and a new adhesive in the experimental phase, T1.

\section{Materials and Methods}

The adhesives were brushed in petri dishes, polymerized, immersed in culture medium, and incubated for $24 \mathrm{~h}$ for extracts preparation. The cytotoxicity experiments were performed in mouse embryo fibroblast cells (NIH/3T3; ATCC CRL-1658) and human osteoblast-like cells from osteosarcoma (MG-63; ATCC CRL-1427) exposed to different extracts dilutions. For cytotoxic evaluation, $1 \times 10^{4}$ cells per well, from passages 8 to 12 , were seeded in 96-well plates (eight replicates) and incubated at $37^{\circ} \mathrm{C}$ for $24 \mathrm{~h}$ under a 
humidified atmosphere of $5 \% \mathrm{CO}_{2}$. After proliferation, the growth medium was removed and replaced with $200 \mu \mathrm{L}$ per well of undiluted extracts or serial dilutions of each adhesive extract (up to 1:50). Unexposed control cells were incubated with growth medium only. MTT assays were performed as previously described [4]. After $24 \mathrm{~h}$ of incubation with the potentially toxic compounds, we measured the formazan crystals formed at $595 \mathrm{~nm}$ absorbance and the unexposed control cells were considered to indicate 100\% cell viability. A minimum of three independent assays were performed. Statistical analysis was performed through an analysis of variance (ANOVA) followed by Tukey's HSD multiple comparison test.

\section{Results and Discussion}

The results obtained for the three adhesives are displayed in Figure 1, as cellular viability after exposure to different adhesive extract concentrations. For 3T3 fibroblasts, the cytotoxicity order obtained of the unfiltered adhesive extracts was T1 (less cytotoxic) < Optibond Solo Plus < Scotchbond Universal (most cytotoxic).

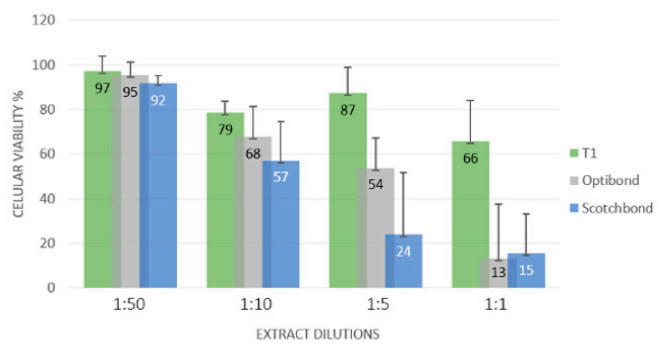

(a)

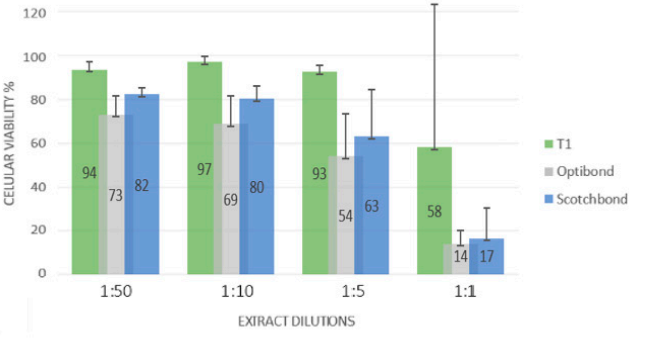

(b)

Figure 1. Cytotoxicity of unfiltered (a) and filtered (b) adhesive materials in 3T3 cells.

For 3T3 fibroblasts, the cytotoxicity order obtained of the filtered adhesive extracts was T1 (less cytotoxic) < Scotchbond Universal < Optibond Solo Plus (most cytotoxic). For MG-63 osteoblasts, the least toxic was also the T1 adhesive, while the most toxic was Scotchbond Universal. Despite the limitations of this in vitro study, we can conclude that the three adhesives present a dose-dependent effect. The filtration of the same extract, or its absence, has effects on the cell viability, as well as the alteration of cell type, with MG-63 being more sensitive in general. In this study, the T1 adhesive is the one with the greatest biocompatibility, and taking into account that it is still in the experimental stage, further studies should be carried out to evaluate other important aspects in clinical practice.

Author Contributions: I.B. and P.M. (Paulo Maurício); Methodology, S.B.; Software, P.M. (Paulo Mascarenhas); Validation, S.S.; I.B.; Writing-Review \& Editing, I.B.; A.C.R.; P.M.: Funding Acquisition, I.B. All authors have read and agreed to the published version of the manuscript.

Funding: The graduate student's thesis program in Dental Medicine from the Cooperativa de Ensino Superior, CRL, Caparica, Portugal.

Informed Consent Statement: Not applicable.

Acknowledgments: This work was done for Sofia Santos's master degree in Dentistry and it was supported by Egas Moniz, Cooperativa de Ensino Superior CRL.

Conflicts of Interest: The authors declare no conflict of interest.

\section{References}

1. Massaro, H.; Zambelli, L.F.; Britto, A.A.D.; Vieira, R.P.; Ligeiro-de-Oliveira, A.P.; Andia, D.C.; Oliveira, M.T.; Lima, A.F. Solvent and hema increase adhesive toxicity and cytokine release from dental pulp cells. Materials 2019, 12, 2750. [CrossRef] [PubMed]

2. Goldberg, M. In vitro and in vivo studies on the toxicity of dental resin components: A review. Clin. Oral Investig. 2008, 12, 1-8. [CrossRef] [PubMed] 
3. Tadin, A.; Gavić, L.; Galić, N. Biocompatibility of dental adhesives. In Adhesives-Applications and Properties; Materials Science; Rudawska, A., Ed.; IntechOpen: London, UK, 2016. [CrossRef]

4. Bandarra, S.; Mascarenhas, P.; Luís, A.R.; Catrau, M.; Bekman, E.; Ribeiro, A.C.; Félix, S.; Caldeira, J.; Barahona, I. In vitro and in silico evaluations of resin-based dental restorative material toxicity. Clin. Oral Investig. 2020, 24, 2691-2700. [CrossRef] [PubMed] 